\title{
FLORESCER DOS FEMINISMOS NA LUTA DAS MULHERES INDÍGENAS E CAMPONESAS DA AMÉRICA LATINA
}

\author{
Flowering of feminisms in the struggle of indigenous and peasant women in \\ Latin America
}

\author{
Lia Pinheiro Barbosa'
}

\begin{abstract}
Resumo
0 presente artigo visa apresentar a concepção de luta das mulheres e de feminismos erigida pelas indígenas e camponesas do campo popular latino-americano. Nesse marco, o escrito destaca dois processos de elaboração teórica em curso, a saber, o Feminismo Camponês e Popular e o Feminismo Comunitário, ambos vinculados à inserção política das mulheres camponesas e indígenas no debate em torno à compreensão teórico-crítica do patriarcado, da opressão de gênero e das vias de construção de sua luta política como mulheres. Adentra-se, ainda, ao contexto de inserção política das Zapatistas com o grito de "Já Basta" e a Lei Revolucionária das Mulheres, com destaque para os elementos teóricoepistêmicos e políticos que articulam a luta das mulheres, e os conceitos de insurgente, revolucionário, rebelde e autônomo das Zapatistas. Outro propósito do artigo consiste em apresentar as interfaces entre as Zapatistas e os feminismos populares na América Latina, em particular com o Feminismo Camponês e Popular e o Feminismo Comunitário.
\end{abstract}

Palavras-chaves: Luta das Mulheres; Camponesas; Indígenas; Feminismos Populares; Zapatistas

\begin{abstract}
This article aims to present the concept of women's struggle and feminism erected by indigenous and peasant women in Latin American popular organizations. In this context, the paper highlights two ongoing processes of theoretical elaboration, namely, Popular Peasant Feminism and Community Feminism, both linked to the political insertion of peasant and indigenous women in the debate around the theoretical-critical understanding of patriarchy, gender oppression and the ways of building their political struggle as women. It also adheres to the context of the political insertion of the Zapatistas with the cry of "Enough is Enough" and the Revolutionary Law of Women, with emphasis on the theoreticalepistemic and political elements that articulate the struggle of women, and the insurgent, revolutionary, rebellious and autonomous concepts of the Zapatistas. Another purpose of the article is to present the interfaces between the Zapatistas and popular feminisms in Latin America, in particular with Popular Peasant Feminism and Community Feminism.
\end{abstract}

Keywords: Women's struggle; Peasant women; Indigenous women; Popular Feminisms; Zapatistas

\section{Introdução}

\footnotetext{
1 Docente no Programa de Pós-Graduação em Sociologia (PPGS) e no Mestrado Acadêmico Intercampi em Educação e Ensino (MAIE) da Universidade Estadual do Ceará (UECE). Pesquisadora do Conselho Latino-Americano de Ciências Sociais (CLACSO) no GT Cuerpos, Territorios y Resistencias e no GT Herencias y perspectivas del Marxismo. E-mail: lia.barbosa@uece.br.
} 
Florescer dos feminismos na luta das mulheres indígenas e camponesas da américa latina | Lia Pinheiro Barbosa

O presente artigo tem por objetivo apresentar a construção histórica da concepção de luta das mulheres e de feminismo erigida pelas indígenas e camponesas vinculadas ao campo popular latino-americano. Nessa direção, o escrito destaca dois processos de elaboração teórica em curso, a saber, o Feminismo Camponês e Popular e o Feminismo Comunitário, ambos vinculados à inserção política das mulheres camponesas e indígenas no debate em torno à compreensão teórico-crítica do patriarcado, da opressão de gênero e dos caminhos para a uma abordagem do(s) feminismo(s) em uma perspectiva popular e articulada à emancipação humana, e o horizonte de luta de suas organizações.

Do mesmo modo, o artigo adentra ao caso específico da ação política das mulheres indígenas Zapatistas, em Chiapas, México, para demonstrar os diálogos tecidos entre essas concepções de feminismo desde o campo popular, ao mesmo tempo em que evidencia as tensões com relação a outras abordagens do feminismo, especialmente ao situarmos a trajetória do feminismo no contexto histórico-social e político da América Latina. Para tanto, o escrito está organizado em cinco sessões: na primeira, apresento o contexto de articulação histórica da resistência indígena e camponesa na América Latina, com o intuito de situar a configuração do campo popular e de sua agenda política na transição de séculos. Nesse contexto, destaco o papel político das mulheres, ao reivindicar a perspectiva de gênero no cerne da luta coletiva de suas organizações, ao mesmo tempo em que aportam no terreno conceitual ao debate dos feminismos populares.

$\mathrm{Na}$ segunda sessão, apresento a inserção politica das Zapatistas com o grito de "Já Basta" e a Insurgência Armada do Exército Zapatista de Libertação Nacional (EZLN). Na terceira sessão, apresento a centralidade da Lei Revolucionária de Mulheres no processo de conformação da subjetividade política das Zapatistas. Na quarta sessão, aprofundo os elementos teóricoepistêmicos e politicos que articulam a luta das mulheres, conceito correlato ao feminismo na perspectiva da mulher indigena, e em uma perspectiva insurgente, revolucionária, rebelde e autônoma, concepção teórica e de projeto político construído a partir das experiências de vida e de luta política das Zapatistas. Finalmente, apresento as tensões e os diálogos estabelecidos entre as mulheres Zapatistas, as teóricas feministas e os feminismos populares na 
Florescer dos feminismos na luta das mulheres indígenas e camponesas da américa latina | Lia Pinheiro Barbosa

América Latina, em particular com o Feminismo Camponês e Popular e o Feminismo Comunitário.

\section{O Abya Yala e os 500 anos de resistência, em coletivo e em pares}

Na Primeira Declaração da Selva Lacandona, o Exército Zapatista de Libertação Nacional (EZLN) afirma: somos produto de 500 anos de luta, alusiva à resistência indígena frente à condição colonial, de opressão e despojo territorial decorrentes da Conquista da América. Na contemporaneidade, os povos indígenas e camponeses interpelam o paradigma da modernidade ocidental capitalista, contrapondo-se a partir de um projeto societário alterno alicerçado em outro paradigma, um paradigma epistêmico do campo (BARBOSA, 2019) que nasce do vínculo idiossincrático com a dimensão epistêmica, identitária e política de seus territórios com o Abya Yala. Nesse marco, ao final do século XX, emerge uma articulação regional em torno da Campanha Continental 500 Anos de Resistência Indigena, Negra e Popular (1989-1992), que expressa a crítica dos movimentos populares frente às celebrações oficiais dos 500 anos da Conquista. Nesse período é fundada a Via Campesina Internacional (LVC) e a Coordenadora Latino-Americana de Organizações do Campo (CLOC), instância de articulação continental da LVC, ${ }^{2}$ uma estratégia popular para confrontar a ofensiva do capital transnacional em escala global, continental e nacional e na disputa de modelos agrários (ROSSET, 2016). Outras resistências populares ocorrem nesse período, como a insurgência armada do EZLN, as marchas dos cocaleiros na Bolivia, além das mobilizações camponesas pela reforma agrária no Brasil, Paraguai e Guatemala.

Nesse contexto histórico, as mulheres têm assumido um papel vital na defesa da terra, dos seus territórios, dos bens naturais e de suas comunidades, amplamente ameaçadas pelo novo padrão de acumulação do capital (FEDERICI, 2014). Na perspectiva das indigenas, essa luta incorpora o desafio de forjar-se como sujeito político, em um movimento reflexivo crítico endógeno-exógeno, em que se problematizam as dimensões históricas do patriarcado e das opressões dele derivadas, seja na esfera institucional do

\footnotetext{
2 Composta por mais de 80 organizações indígenas, camponesas, afrodescendentes, de trabalhadores rurais, de pescadores, ribeirinhos, entre outras organizações de 18 países da América Latina e do Caribe. Dados disponiveis em: http://www.cloc-viacampesina.net/
} 
Florescer dos feminismos na luta das mulheres indígenas e camponesas da américa latina | Lia Pinheiro Barbosa

Estado ou no terreno público e privado das relações intersubjetivas do tecido social comunitário. Portanto, pressupõe forjar a própria consciência histórica em coletivo (em suas comunidades e organizações) e em pares (mulheres e homens) no desafio de descolonizar-se, ou seja, "pensar-se a partir do centro do nosso ser, fazer a reflexão teórico-epistêmica da forma como temos assumido nosso lugar no mundo" (MÉNDEZ-TORRES, 2013, p. 33, tradução nossa). Para as indígenas, descolonizar prescinde debater três aspectos fundamentais: quem ocupa o lugar material da reflexão tardia sobre o sujeito $e$ os corpos do feminismo (CHIRIZ, 2013; ESPINOSA-MIÑOSO, 2014); a colonização discursiva e o privilégio epistêmico da prática acadêmica do feminismo ocidental (MOHANTY, 2008) e as aprendizagens na descolonização do feminismo (MÉNDEZ-TORRES, 2013; HERNÁNDEZ-CASTILLO, 2014).

Ao tecer a critica ao feminismo ocidental, as mulheres indigenas tencionam uma abertura a outras concepções e práticas no campo dos feminismos, erigidas a partir de marcos epistemológicos e ontológicos provenientes de suas cosmovisões, da matriz linguística, de seus contextos culturais e de ação política, e evidenciam tensões entre sua autoafirmação como indígenas que constroem uma concepção própria de luta como mulheres e outras vertentes do feminismo. Para tanto, consideram fundamental colocar em perspectiva esses três aspectos, sobretudo para problematizar onde subjaz o exercício de poder na escrita das mulheres mestiças e ocidentais sobre as outras mulheres (CHIRIX, 2013). Também para delimitar outros parâmetros conceituais e de posicionamento político para as lutas das mulheres que não se autodenominam nos marcos da categoria feminismo, e que reivindicam suas lutas enraizadas às lutas políticas de suas organizações, construídas em coletivo e em pares.

Exemplar dessa especificidade é o debate aberto pela Articulação de Mulheres do Campo da CLOC/LVC, pelas indígenas bolivianas e pelas indígenas Zapatistas, quem têm tecido uma concepção própria para suas lutas e demandas políticas no enfrentamento das desigualdades, hierarquias e opressões de gênero, em um debate contínuo com suas comunidades e no âmbito das lutas que participam. No contexto dos feminismos populares, de uma reflexão em torno à justiça de gênero, à transnacionalização do feminismo e num diálogo mediado por outras genealogias, emergem outras 
Florescer dos feminismos na luta das mulheres indígenas e camponesas da américa latina | Lia Pinheiro Barbosa

concepções que expressam o exercício legítimo de autonomia epistêmica. Para fins da presente reflexão, farei uma aproximação ao Feminismo Camponês e Popular e ao Feminismo Comunitário, reconhecendo-os como uma teoria social genuína em torno à luta das mulheres e sua apreensão do feminismo. Para tanto, sublinharei suas convergências analíticas em relação à concepção de luta das mulheres Zapatistas, com o intuito de apresentar outras concepções que aportam aos feminismos populares chaves interpretativas, ademais de lançar luzes às tensões e dilemas contemporâneos em torno aos feminismos.

\title{
Feminismo Camponês e Popular
}

O Feminismo Camponês e Popular se define como uma teoria social e projeto político em construção da Articulação de Mulheres da CLOC/LVC. No I Congresso da CLOC, em 1994, debateu-se a necessidade de uma maior participação política das mulheres e de construção de um olhar próprio como camponesas, acerca da temática da terra, do território, da reforma agrária, das sementes e o acesso a créditos, entre outras questões relacionadas à agenda política da CLOC. Para elas, o enfoque de gênero e a paridade de participação eram imprescindiveis a sua estratégia politica. $\mathrm{Na}$ Declaração Final do Congresso da CLOC, afirmaram: ${ }^{3}$

\begin{abstract}
A luta das mulheres do campo é a luta de todos; não é apenas um problema das mulheres, mas de todos os explorados, de toda a sociedade. Trabalharemos por uma mística latino-americana que supere todo tipo de discriminação e violência contra a mulher, facilitando, apoiando sua participação ativa e com direitos iguais aos do homem nas diferentes instâncias de decisão (Tradução nossa).
\end{abstract}

As mulheres da CLOC conformaram a Articulação de Mulheres do Campo com o intuito de promover espaços permanentes de mobilização, organização, articulação e formação política em torno a sua condição de mulheres do campo, em suas próprias comunidades e famílias, bem como em relação à transversalidade do gênero em todos os espaços políticos e de direção da CLOC/LVC. O conceito de gênero tem sido balizar nessa trajetória, porém insuficiente ante as especificidades e o aprofundamento das demandas politicas das mulheres, posto que "o sujeito (as mulheres camponesas) permanece invisivel: estão à margem. Além disso, falam das mulheres em sua

3 Disponivel em: http://www.cloc-viacampesina.net/congresos/i-congreso. Data de acesso: janeiro de 2018. 
Florescer dos feminismos na luta das mulheres indígenas e camponesas da américa latina | Lia Pinheiro Barbosa

globalidade, sem uma especificidade da realidade própria das mulheres camponesas. [...] as camponesas percebem que há muitos feminismos, porém com outras perspectivas" (SEIBERT, 2017, tradução nossa). ${ }^{4}$

$\mathrm{Na}$ Declaração da IV Assembleia da Articulação das Mulheres do Campo, em 2009, se amplia o escopo teórico-político, ao assumir o "feminismo, camponês, popular, com identidade e revolucionário" como marco de uma concepção de feminismo própria, compreendida como estratégia política para a emancipação das mulheres frente ao patriarcado e à ofensiva do capital transnacional no campo que atenta, diretamente, sobre suas vidas, seus corpos e seus territórios.

O caráter popular da concepção de feminismo da Articulação de Mulheres do Campo advém da natureza política das organizações da CLOC, em sua maioria de natureza mista. Entretanto, ao definir sua concepção como feminismo camponês e popular incorporam outras matrizes de sua reflexão coletiva como mulheres: camponês, porque se reconhecem como classe trabalhadora do campo, com um ethos identitário e politico com a terra e o território; popular, por ser uma construção coletiva das organizações do campo popular, e não obra de uma corrente de pensamento ou de uma teoria do feminismo (ANAMURI, 2015). Na V Assembleia da Articulação das Mulheres do Campo, em 2015, assumem o feminismo com identidade própria (a camponesa) e de construção coletiva (popular). Na Declaração Final do Congresso da CLOC afirmam que o patriarcado: ${ }^{5}$

É um sistema de opressão que foi estruturalmente incorporado pelo capitalismo, porque lhe permite manter e fortalecer as relações de poder e exploração, e nos atinge de maneira mais brutal às mulheres. Somos as mulheres pobres as que sofremos o fardo múltiplo da subordinação, a discriminação de gênero, a exploração de classe, o racismo e o sexismo (Tradução nossa).

A interseção entre as categorias classe, etnia/raça e gênero é central para a compreensão dos fundamentos teórico-epistêmicos e políticos do Feminismo Camponês e Popular, sobretudo na apreensão da dialética das opressões intrinsecas às três categorias e que estigmatiza triplamente as mulheres subalternizadas. Conforme Masioli (2015, p. 59):

\footnotetext{
4 Disponivel em: http://www.soberaniaalimentaria.info/numeros-publicados/60-numero-29/454feminismo-campesino-y-popular. Data de acesso: março de 2018.

5 Disponivel em: http://www.cloc-viacampesina.net/congresos/v-asamblea-de-mujeres. Acesso em janeiro de 2018.
} 
Florescer dos feminismos na luta das mulheres indígenas e camponesas da américa latina | Lia Pinheiro Barbosa

À medida que as mulheres tomam consciência de classe e condição de gênero, elas percebem que sua contribuição histórica tem sido a de confrontar o modelo capitalista e a destruição radical do modelo patriarcal que subordina as mulheres mediante a imposição de padrões de comportamento e o domínio do seu corpo (Tradução nossa).

Para a Articulação de Mulheres do Campo, a emancipação das mulheres prescinde a superação do patriarcado e do capitalismo, considerados sistemas de opressão e exploração de mulheres e homens. Daí que afirmam (CASTRO, 2015, p. 65):

Nossos inimigos não são os homens, nem o sexo masculino, mas o patriarcado e o capitalismo que explora a ambos os sexos, impondo papéis e padrões culturais que regem e controlam nossa classe e nossos corpos. [...] Compreender nosso feminismo a partir de um enfoque de classe, emancipa-nos e posiciona-nos a partir de uma dissidência ao modelo capitalista-patriarcal (Tradução nossa).

É fundamental destacar que durante o V Congresso da CLOC, realizado no Equador em 2010, as mulheres mapuches da Asociación Nacional de Mujeres Rurales e Indigenas (ANAMURI) reivindicaram a perspectiva étnica como elemento a ser incorporado à elaboração teórica do Feminismo Camponês e Popular. Para as mapuches, o conceito de feminismo não atende à totalidade de suas especificidades como mulheres indígenas e, portanto, não deve ser assumido como uma linguagem universal e única para expressar a luta contra as violências de gênero sofridas pelas mulheres. $\mathrm{Na}$ ótica das mapuches, inclusive, essa categoria é considerada alheia ao seu modo de vida e a sua cosmovisão. Entre as principais críticas e tensões apontadas pelas mapuches com relação a outras correntes feministas, sobretudo dos feminismos urbanos, destacam-se: a tendência a sobrepor suas perspectivas teóricas e de estratégias de luta em contextos culturalmente distintos, sobretudo com a intenção de "regatá-las do patriarcado indígena"; o trato colonial e folclórico dispendido às mulheres mapuches; a presença do racismo e da discriminação dentro do próprio movimento de mulheres e dos feminismos. 6

Apesar dessas tensões, as mapuches consideram que o feminismo, enquanto elaboração conceitual, constitui uma ferramenta importante para a análise de suas próprias realidades no âmbito da luta antipatriarcal e

\footnotetext{
6 Para uma aproximação às tensões e aos desafios concernentes à incorporação da etnia no marco do Feminismo Camponês e Popular e de outras correntes do feminismo, sugiro a reflexão de Millaray Painemal e Isabel Cañet: http://www.eldesconcierto.cl/2018/03/04/es-que-acaso-debemos-ser-todasfeministas-reflexiones-de-mujeres-mapuche-para-un-debate/. Data de acesso: setembro de 2018.
} 
Florescer dos feminismos na luta das mulheres indígenas e camponesas da américa latina | Lia Pinheiro Barbosa

anticapitalista. E mesmo que a etnia não tenha sido incorporada explicitamente na proposta teórico-política do Feminismo Camponês e Popular, está presente no debate interno e nos espaços de formação política da Articulação de Mulheres do Campo da CLOC. ${ }^{7}$

Em 2017, na VII Conferência Internacional da LVC, a Articulação de Mulheres do Campo apresentou os aportes do Feminismo Camponês e Popular na estratégia politica para a emancipação das mulheres da CLOC na América Latina e Caribe. Reafirmaram que é uma construção permanente e pariforme à luta da LVC como movimento social transnacional, sobretudo pelo papel político das mulheres para a agroecologia, a soberania alimentar e a defesa dos territórios, em escala global.

A Articulação de Mulheres do Campo da CLOC defende que a estratégia política para superação do capitalismo e do patriarcado, bem como na transição ao socialismo prescinde do reconhecimento do feminismo como uma teoria social e projeto político. Daí que as principais consignas do Feminismo Camponês e Popular é "Sem Feminismo, Não há Socialismo" e "Sem Feminismo, Não há Agroecologia”. Durante a VI Assembleia de Mulheres da CLOC/LVC, realizada em 2019 em Cuba, a Articulação de Mulheres do Campo demarcou outra consigna "Com Feminismo, Construimos Socialismo".

\section{Feminismo Comunitário}

O Feminismo Comunitário nasce no contexto de resistência das organizações populares e movimentos indígenas da Bolivia, intensificado a partir de 2003, ano de fortalecimento do campo popular na disputa por uma refundação do Estado e de uma nova Constituição Plurinacional. Nesse cenário, as indigenas bolivianas se posicionaram com o intuito de aprofundar sua própria reflexão em torno ao papel que deveriam assumir nessa nova etapa da luta popular, que culminou com a concepção do Feminismo Comunitário.

\footnotetext{
7 Principalmente nas discussões realizadas nas Assembleias da Articulação de Mulheres da CLOC, ocasião em que debatem a construção teórica do Feminismo Camponês e Popular. As assembleias têm se configurado em um espaço onde se explicitam as tensões internas e as reivindicações da inserção da abordagem étnica à elaboração teórica articulada pelas mulheres da CLOC. Por se tratar de um conceito ainda em construção, perduram as reflexões, as problematizações e as reivindicações concernentes à incorporação explícita da categoria etnia/etnicidade ao Feminismo Camponês e Popular.
} 
Florescer dos feminismos na luta das mulheres indígenas e camponesas da américa latina | Lia Pinheiro Barbosa

Concebido como uma teoria social, o Feminismo Comunitário visa construir ferramentas teóricas para elucidar as raizes históricas do patriarcado e suas dimensões de opressão sobre os corpos das mulheres indígenas. Uma das categorias centrais criadas pela xinca guatemalteca Lorena Cabnal (2010) é a de território-corpo-terra, concebida para enfrentar a exploração e o extrativismo mineiro no marco da política neoliberal. Para Cabnal (2010), o Feminismo Comunitário surge para reinterpretar as realidades históricas da vida cotidiana das mulheres indígenas, a partir da cosmovisão e do mundo indígena, com o intuito de contribuir com a pluralidade de feminismos, de transgressões e epistemologias no contexto mais amplo de luta das mulheres na ruptura do patriarcado ancestral e ocidental.

Em seu marco epistemológico, um dos fundamentos do Feminismo Comunitário é o Warmi-Chacha, o par-político Mulher-Homem, contudo: ${ }^{8}$

[...] não deve confudir-se com o casamento ou casal heterossexual, mas sim falamos da representação politica das Mulheres e da representação política dos Homens. Uma medida política que permitirá buscar as soluções que contenham as contribuições, o pensamento, a opinião e a proposta das mulheres, que são as mais empobrecidas, invisibilizadas e desterradas, dos pensamentos políticos, filosóficos e espirituais do planeta (Tradução nossa).

Historicamente, o patriarcado se constituiu como um sistema organizado por uma matriz de pensamento que nega a palavra das mulheres e as expressões do feminino nas esferas simbólico-ideológica, espiritual e material da vida. Para o Feminismo Comunitário, o patriarcado constitui o sistema que promove todas as opressões e as violências sentidas por mulheres e homens, e se constitui sobre os corpos das mulheres. Galindo (2013) argumenta que a presença do patriarcado nas relações de gênero das sociedades indígenas é preexistente à Conquista, e se manifestava no que Galindo denomina de patriarcado ancestral. Com a colonização há o encontro entre o patriarcado ancestral e o patriarcado da Conquista, processo histórico que fortaleceu o patriarcado como sistema de opressões, uma vez que o colonialismo outorgou aos homens indígenas privilégios patriarcais preexistentes e que continuaram reproduzindo-se após a colonização.

\footnotetext{
8 Discurso lido pelas mulheres no Encontro entre os Movimentos Populares e o Papa Francisco, em 2015, na Bolivia.
} 
Florescer dos feminismos na luta das mulheres indígenas e camponesas da américa latina | Lia Pinheiro Barbosa

Nessa linha, Segato (2012) formula o quadro analítico de "patriarcado de baixa intensidade" para demonstrar que a natureza das relações de gênero se modifica historicamente pelo colonialismo e legitima o patriarcado nas diferentes etapas da história pré e pós-coloniais. Conforme Guzmán, "por isso que nesses territórios do Abya Yala, as mulheres vivemos um duplo patriarcado que oprime não só às mulheres, mas também os homens e a natureza, porque existe este entroncamento patriarcal" (Tradução nossa).${ }^{9} \mathrm{O}$ Warmi-Chacha representa o ideário das posições de sujeito - mulher e homem - em uma sociedade emancipada do patriarcado.

É válido destacar outras interpretações feministas indígenas que discordam do argumento da existência de um patriarcado ancestral, conforme defendido pelo Feminismo Comunitário (SMITH, 2005; ALTAMIRANOJIMENEZ, 2013; GREEN, 2017), com a premissa de que em sociedades indígenas pré-coloniais do Canadá e dos Estados Unidos existiam ordens de gênero diferentes e mais igualitárias. Um exemplo a ser tomado é o da cultura Navajo, na região fronteiriça com o México, em que coexistem quatro categorias de gênero: mulher, mulher masculina, homem masculino, homem feminino.

Retomando o conceito de entroncamento patriarcal, este problematiza outras categorias elaboradas pelas teóricas feministas, como a interseccionalidade, por considerá-la insuficiente à análise do patriarcado situado desde outra genealogia histórica e abordagem epistêmica. Por ser compreendido como um sistema de opressões construído historicamente e que legitima privilégios aos homens, independentemente de sua condição de classe e/ou raça, não é suficiente delimitar a superação do patriarcado tão somente na transição de um modelo de sociedade a outro, uma vez que os privilégios concedidos aos homens permaneceriam intocáveis. Para tanto, o Feminismo Comunitário defende a despatriarcalização e a descolonização a partir do fundamento teórico-epistêmico das chamadas "Quatro D", aporte do campo popular boliviano no enfrentamento do sistema patriarcal, colonial e capitalista neoliberal: Primeira D - desde os povos originários e as organizações populares se constroem os processos de libertação; Segunda D - despatriarcalização dos Estados e sociedades, dado que a lógica do

\footnotetext{
9 Vídeo Feminismo Comunitário, produzido pelo Coletivo Koman Ilel - Mirada Colectiva.
} 
Florescer dos feminismos na luta das mulheres indígenas e camponesas da américa latina | Lia Pinheiro Barbosa

patriarcado conduz a racionalidade depredadora do capitalismo e das guerras; Terceira D - descolonização dos corpos, das culturas, das espiritualidades e dos territórios; Quarta D - desneoliberalização anticapitalista das economias, do trabalho e da produção.

O Feminismo Comunitário se posiciona em uma crítica teóricoepistêmica ao pensamento filosófico euro-ocidental ou euro-ocidentalizado em duas perspectivas: na abordagem dicotômica colonial, que legitima dualidades analíticas para uma interpretação do processo civilizatório, por exemplo, no par "civilizado-incivilizado", "pré-moderno-moderno", entre outras categorizações que têm assumido um papel hegemônico na conformação de um pensamento social, de uma teoria que se pretende universal, e que não tem abertura ao diálogo com outras racionalidades e posições de sujeitos. A segunda crítica recai sobre a concepção temporal das relações sociais, em que se demarca como alvorada civilizatória a Conquista. A propósito dessa análise, destaca Cusicanqui (1984, p. 54-55):

[...] não há "pós" nem "pré" em uma visão da história que não é linear nem teleológica, que se movimenta em ciclos espirais, que marca uma direção sem deixar de voltar ao mesmo ponto. O mundo indígena não concebe a história linearmente, e o passado-futuro estão contidos no presente (Tradução nossa).

O Feminismo Comunitário tece sua crítica ao feminismo ocidental como ideário conceitual e político, sobretudo nas categorias analíticas baseadas na lógica dicotômica colonial, em que o patriarcado se resume às relações de dominação de homens em direção às mulheres. Finalmente, no debate teórico-político do Feminismo Comunitário, as mulheres consideram que não é possível falar de um feminismo na América Latina e no Caribe tão somente em uma perspectiva de igualdade de gênero, igualdade de diferença, de luta pelos direitos laborais, reprodutivos, quando na região as lutas travadas pelos povos originários buscam construir outros modos de vida para a humanidade e a natureza. Há uma ruptura com a abordagem segmentada/ fragmentada do patriarcado e da luta das mulheres, e com os exercícios de poder de uma teoria feminista ocidental hegemônica. Para tanto, defendem um feminismo útil para a luta dos povos, dos quais são parte constitutiva como mulheres, em que haja autonomia epistêmica para construir seus referentes teóricos interpretativos, ou mesmo para preencher de conteúdo categorias aprendidas dos outros feminismos. 
Florescer dos feminismos na luta das mulheres indígenas e camponesas da américa latina | Lia Pinheiro Barbosa

O Feminismo Camponês e Popular e o Feminismo Comunitário são expressões contemporâneas de outras genealogias teórico-políticas dos feminismos populares e da luta das mulheres na América Latina. Vejamos suas interfaces com a luta das Zapatistas, outra experiência do campo popular dos feminismos.

\section{O “Já Basta" rebelde e insurgente das mulheres Zapatistas}

No Encontro das Mulheres Zapatistas com as Mulheres do Mundo, em 2007, uma zapatista relatou: 10

Ele nos tinha como animal. Chegou um dia em que o patrão ordenou ao povo, que fossem buscar, pois, os pais, as mocinhas, para que ele as pudesse estuprar. Assim faziam os patrões estes [sic]. [...] Só viam [os pais] que estuprava as mocinhas. Todas as mocinhas (Tradução nossa).

Nos contextos de colonização, marcados por um profundo racismo, a violência sexual, representa uma recolonização do corpo da mulher indígena, no sentido de atribuir-lhe o caráter de extensão territorial circunscrito ao domínio do conquistador, na reafirmação da posse irrestrita como um direito inerente à conquista. Recai sobre os corpos das mulheres indígenas a sentença de tornar-se um corpo sem alma, Sem Rosto e Sem Voz. Entretanto, no movimento dialético da história social, as raízes da subalternização demarcam a natureza das resistências e são capazes de subverter a ordem social imperante, ao deslocar os sentidos da violência naturalizada, institucionalizada: a condição de ser um(a) Sem Rosto é (re)significada e se torna uma identidade política, de luta, de insurgência.

A insurgência armada de um exército indígena, o EZLN, é exemplar da luta insurreta dos Sem Rosto. O alçamento armado de 01 de janeiro de 1994 expressava a resistência explícita à entrada em vigor do Tratado de Livre Comércio (TLC), que legitimaria a expropriação territorial dos recursos hídricos e minerais existentes nos territórios indígenas do México, especialmente em Chiapas, região de interesse estratégico do capital transnacional (BARBOSA, 2016). Outras razões foram a exigência da modificação do artigo 27 da Constituição, referente aos fundamentos básicos do Pacto Agrário, uma das mais expressivas conquistas da Revolução

\footnotetext{
10 Disponivel em: https://www.youtube.com/watch?v=aWkKwdGKtxE. Data de acesso: janeiro de 2018.
} 
Florescer dos feminismos na luta das mulheres indígenas e camponesas da américa latina | Lia Pinheiro Barbosa

Mexicana de 1910. Nesse marco, se deu uma reivindicação, nos planos jurídico e político, do reconhecimento dos direitos coletivos dos povos indígenas, pauta política aprimorada pela demanda de livre determinação e autonomia em seus territórios (BARBOSA, 2015; 2016).

O México constitui um país pluriétnico e plurilinguístico, características que também atravessam a conformação de alguns movimentos indígenas e a natureza de suas demandas étnico-políticas. Tal é o caso do Zapatismo, movimento de composição heterogênea, conformada pelas etnias maias falantes das línguas tojolabal, tzotzil, tseltal e ch'ol. Na organização de sua estrutura política, o Movimento Zapatista possui um corpo civil, o Comitê Clandestino Revolucionário Indígena - Comandância Geral (CCRI-CG), e o corpo militar, representado pelo EZLN. O CCRI-CG está composto por um grupo seleto de comandantes e comandantas provenientes de todas as comunidades. Com uma posição social correlata a um Conselho de Autoridades ou Conselho de Anciãos, o CCRI-CG desempenha atividades correspondentes ao sistema de cargos, portanto, obedece às regras da democracia tradicional indigena, baseadas na câmara municipal aberta e na assembleia comunitária, instância de discussão e tomada de decisões por meio do consenso e do referendum, com a participação de homens, mulheres, crianças e idosos, com direito de voto e voz (ARMAS, 2008).

Em 1994, um terço das fileiras do EZLN era formado por mulheres, entre elas doze em posições de mando, como capitãs, tenentes, major, subtenentes. Duas delas à frente da ocupação militar zapatista da cidade de San Cristóbal de las Casas: a Comandanta Ramona e a Major Ana María. Na abertura do I Encontro Intercontinental pela Humanidade e Contra o Neoliberalismo, a Major Ana María anunciou o sentido político e epistêmico de ser um(a) Sem Rosto (EZLN, 1996, p. 25):

Isto somos nós. [...] a voz que se arma para fazer-se ouvir. O rosto que
se esconde para mostrar-se. O nome que se silencia para ser nomeado.
[...] Por trás do nosso passa-montanha está o rosto de todas as
mulheres excluídas. De todos os indígenas esquecidos (Tradução
nossa).

Outro fator central para a rebelião zapatista foi a alta taxa de mortalidade infantil indígena e seu significado político para a história e a 
Florescer dos feminismos na luta das mulheres indígenas e camponesas da américa latina | Lia Pinheiro Barbosa

memória dos povos indigenas. ${ }^{11}$ A luta pelo direito de viver dignamente constituiu a chama da rebeldia das mulheres Zapatistas. A ela, soma-se a demanda pela modificação do artigo $4^{\circ}$ da Constituição Mexicana que determina, no âmbito das decisões agrárias, a supremacia dos homens sobre os direitos garantidos pela lei dos usos e costumes indígenas. De acordo com a lei de usos e costumes, as mulheres indígenas não têm direito a comprar ou herdar a terra, razão pela qual as Zapatistas exigiam uma alteração do seu artigo $4^{\circ} .{ }^{12}$ Há uma invisibilidade jurídica das indígenas, um mecanismo de reprodução da negação histórica de direitos, estratégia jurídica intrínseca à lógica estrutural de apropriação dos territórios, baseada no processo de erosão dos direitos "tradicionais" das mulheres e de sua participação nos sistemas de terras comunais (FEDERECI, 2014). A propósito da organização política das mulheres indigenas, a Comandanta Hortensia enfatiza (EZLN, 1996, p. 19-20):

Nós, as mulheres, somos as que mais temos sofrido as grandes injustiças de humilhação, porque nós, as mulheres, somos as que menos oportunidades tivemos para viver dignamente, nunca tivemos direito a nenhum tipo de serviço. Por isso, as mulheres indigenas zapatistas tomamos a decisão de lutar para conquistar o lugar que nos corresponde como mulheres (Tradução nossa).

Com a consolidação da autonomia nos territórios zapatistas, há o incremento da Guerra de Baixa Intensidade (GBI), resposta imediata do Estado mexicano frente à resistência indigena. A contrainsurgência torna-se um instrumento da política etnocida do Estado, caracterizada pela ação violenta do exército federal e de paramilitares nos territórios indígenas. $\mathrm{Na}$ GBI, as mulheres tornam-se um alvo estratégico, recaindo mais uma vez sobre seus corpos as atrocidades que atravessam os contextos de guerra: privações, execuções e violência sexual.

A dialética da guerra nos corpos das mulheres torna-se o cerne do debate político das Zapatistas. No I Encontro Intercontinental pela Humanidade e Contra o Neoliberalismo, em 1996, estas enfatizaram o patriarcado como fundamento do neoliberalismo e da expropriação territorial

\footnotetext{
11 Nesse marco, mas mulheres desempenharam um papel central na Insurgência Armada. Conforme o Subcomandante Insurgente Marcos (2009: 19): "Foram as mulheres que começaram a empurrar isto. Não foram os homens. [...] quem começou a empurrar: é preciso fazer algo, já não, e já basta, foram as mulheres que viam seus filhos e filhas morrer. [...] E aí tínhamos duas companheiras que tinham sido, e ainda são, a coluna vertebral nesse trabalho: a finada Comandanta Ramona e a Comandanta Susana". 12 A modificação do artigo $4^{\circ}$ da Constituição Mexicana nunca foi feita e as indígenas continuam sem o direito de comprar ou herdar terra.
} 
Florescer dos feminismos na luta das mulheres indígenas e camponesas da américa latina | Lia Pinheiro Barbosa

impulsada pelo capital transnacional. As Zapatistas destacaram a urgência na compreensão das raízes históricas do patriarcado e em situar o gênero como uma categoria a ser incorporada à crítica do neoliberalismo como projeto político (EZLN, 1996). Ao reivindicar o direito de participação política na defesa de seus territórios, se constrói uma perspectiva própria de inserção política como mulheres indígenas, construída em intrínseca relação com a cosmovisão e com a luta autonômica Zapatista.

\section{A Lei Revolucionária de Mulheres}

A articulação da luta das Zapatistas evidencia uma formação politica de base, um trabalho de convencimento por meio da Pedagogia da Palavra e da ação dialógica entre mulheres (BARBOSA, 2018). No período de clandestinidade, prévio ao levantamento, coube às primeiras mulheres, em particular as Comandantas Ramona e Susana, percorrer suas comunidades para sensibilizar e convocar outras mulheres a unir-se à luta. O debate gerado entre elas abriu caminho para um processo de formação politica, cujo núcleo reflexivo comum se centrava na histórica condição subalterna das indígenas, contexto propício à elaboração de um dos mais significativos documentos da e para a luta política das indígenas no México e na América Latina: a Lei Revolucionária de Mulheres. Aprovada em março de 1993, a referida lei condensa a voz coletiva de todas as Zapatistas que participaram vivamente em sua formulação e que conquistaram sua unânime aprovação em assembleia, sob aplausos femininos e inquietudes masculinas (EZLN, 1994). A Lei Revolucionária de Mulheres é anterior à insurgência armada e preconiza (EZLN, 1994):

Em sua justa luta pela libertação de nosso povo, o EZLN incorpora às mulheres na luta revolucionária sem importar sua raça, crença, cor ou filiação política, com o único requisito de fazer suas as demandas do povo explorado e seu compromisso a cumprir e fazer cumprir as leis e regulamentos da revolução. Além disso, levando em consideração a situação da mulher trabalhadora no México, se incorporam suas justas demandas de igualdade e justiça na seguinte LEI REVOLUCIONÁRIA DE MULHERES: Primeiro. - As mulheres, sem importar sua raça, crença, cor ou filiação política, tem o direito a participar na luta revolucionária no lugar e grau que sua vontade e capacidade determinem. Segundo. - As mulheres têm direito a trabalhar e receber um salário justo. Terceiro. - As mulheres têm direito a decidir o número de filhos que podem ter e cuidar. Quarto. As mulheres têm direito a participar nos assuntos da comunidade e ter cargo se são eleitas livre e democraticamente. Quinto. - As mulheres, e seus filhos, têm direito à ATENÇÃO PRIMÁRIA em sua 
Florescer dos feminismos na luta das mulheres indígenas e camponesas da américa latina | Lia Pinheiro Barbosa

saúde e alimentação. Sexto. - As mulheres têm direito à educação. Sétimo. - As mulheres têm direito a escolher seu companheiro e não ser obrigadas à força a casar-se. Oitavo. - Nenhuma mulher poderá apanhar ou ser maltratada fisicamente nem por familiares nem por estranhos. Nono. - As mulheres poderão ocupar cargos de direção na organização e ter graus militares nas forças armadas revolucionárias. Décimo. - As mulheres terão todos os direitos e obrigações que destaca as leis e regulamentos revolucionários (Tradução nossa).

A Lei Revolucionária de Mulheres é um marco normativo dos direitos e aspirações das mulheres indigenas e de posições de sujeito (ESPINOSAMINOSO, 2014) frente à longa noite dos 500 anos, que condenou as indígenas à violência sexual, física e epistêmica, à negação de uma existência digna como ser humano. Ao propor uma lei que antecipa um processo revolucionário, é anunciado o horizonte político de ruptura com o entroncamento patriarcal, no despertar de uma subjetividade feminista zapatista, que é tecida no transcurso da rearticulação comunitária prévia à Insurgência Armada, condição imprescindivel na conformação do sujeito histórico-político Zapatista. A Lei Revolucionária cobra vitalidade graças à confiança na palavra, apreendida como motor da revolução Zapatista (MILlÁN, 1996). No âmbito das demandas gerais da comunidade, as Zapatistas começam a inserir as demandas específicas das mulheres, em um movimento dialético de permanência - câmbio (MILLÁN, 1996): ao mesmo tempo em que reivindicam seu direito de participação na tomada de decisões e na ocupação de cargos, desejam mudar os costumes, isto é, a tradição, na qual predomina relações de dominação, segregação e maltrato. Conforme a Comandanta Yolanda (EZLN, 2001, p. 219):

É verdade que existem costumes [tradições] que não são tão bons, por exemplo, a embriaguez, essa não é uma boa cultura, nem a de se casar à força. O que nós fazemos é lutar para mudar pouco a pouco, para que melhore. Porém, nossa cultura da forma de trabalhar, de fazer os artesanatos e muito mais coisas, temos uma cultura que não pode se perder (Tradução nossa).

Atrelada à Lei Revolucionária de Mulheres está a proibição do consumo de álcool no território zapatista. O próprio inciso oitavo da lei - nenhuma mulher poderá apanhar ou ser maltrata fisicamente nem por familiares nem por estranhos. Os delitos de tentativas de estupro ou estupro serão castigadas severamente - revela a conquista das Zapatistas no enfrentamento da violência doméstica ocasionada, muitas vezes, pelo consumo de bebidas alcóolicas. 
Florescer dos feminismos na luta das mulheres indígenas e camponesas da américa latina | Lia Pinheiro Barbosa

O inciso sexto da Lei Revolucionária de Mulheres - as mulheres têm direito à educação - foi fundamental no fortalecimento da formação educativa e política das Zapatistas. A Capitã Elisa, afirma: "quando eu vivia na minha casa com minha família, eu não sabia nada. Não sabia ler, não fui à escola, porém quando me integrei ao EZLN, aprendi a ler, tudo o que sei, falar espanhol, escrever, a ler e treinei para fazer a guerra" (Tradução nossa). ${ }^{13} \mathrm{Com}$ o advento da Lei Revolucionária, as Zapatistas paulatinamente assumiram cargos civis e militares, ademais de conquistarem o direito à educação formal. Conforme uma Coordenadora de Área do Caracol III (EZLN, 2013, p. 42):

\begin{abstract}
Bem sabemos que nossa Lei Revolucionária de Mulheres diz que nós temos o direito à educação para que nós também aprendamos a ler e a escrever, porém não só isso, também é para que aprendamos, para defendermo-nos como mulheres porque já não queremos que seja como antes, quando estávamos muito exploradas [...] É necessário que nos eduquemos, que nos preparamos, para que assim ninguém nos engane nem nos explore como mulheres (Tradução nossa).
\end{abstract}

Reivindicar o direito de estudar vai muito além do acesso à escola, uma vez que anseia pela ruptura histórica com o racismo epistêmico, que sentou as bases de uma hierarquia social erigida por matrizes raciais e étnicas (VIVEROS-VIGOYA, 2008; CHIRIX, 2013), e que consolidou, no plano simbólico-ideológico, uma supremacia branca. Sob a base dessa supremacia, se ergueram as posições de dominação e subordinação, as opressões, os atributos estigmatizantes e o controle sobre os corpos das indígenas. Reivindicar o direito à educação é um ato político de subversão da dialética colonial e de autoridade epistêmica, uma vez que ao tomar a palavra como mulheres indigenas, se apropriam do direito de fala e de uma fala posicionada em 500 anos de luta. Na perspectiva da reivindicação dos direitos, a aprendizagem do espanhol (castilla) possibilita enlaçar-se com o mundo "kaxlan" (mestiço), para evitar marginações, abusos e "poder se defender". A demanda coletiva por essa aprendizagem é suscitada em virtude da intensificação da GBI em suas comunidades, o que requer um domínio da linguagem jurídica para fins de denúncia e de exigência de justiça.

Está claro, portanto, que a castilla é a língua que media o discurso institucional do Estado patriarcal e que define hegemonicamente a concepção de justiça e de direitos na perspectiva do privilégio branco, uma construção

13 Periódico La Jornada, Secc. El País. Janeiro de 1994. 
Florescer dos feminismos na luta das mulheres indígenas e camponesas da américa latina | Lia Pinheiro Barbosa

histórica inerente ao projeto colonial na América Latina e que o transcende, ao reproduzir-se na normativa do direito constitucional do Estado-nação moderno e sua capacidade de veto aos direitos às populações indígenas e, em particular, às mulheres indígenas. Nessa direção, educar-se possibilita a apropriação dos códigos jurídicos e o questionamento da autoridade epistemológica do Estado e da racionalidade ocidental moderna. Com o aprendizado da castilla, as Zapatistas disputam a linguagem jurídica, ao fundar as bases da Justiça Autônoma Zapatista, com a outorga da primeira lei vigente em seus territórios, a Lei Revolucionária de Mulheres, construída coletivamente por elas, em suas línguas maternas, porém escrita em espanhol, para demarcar sua posição de sujeito e sua autonomia epistêmica como pioneiras na elaboração de um marco jurídico para o enfrentamento do entroncamento patriarcal na letra da lei.

Outro fator relevante na aprendizagem da castilla estava relacionado à formação política e militar no EZLN: algumas insurgentas relatam que por ser tratar de um exército clandestino conformado por indígenas de diferentes etnias, portanto, de diferentes linguas, o espanhol se tornou a língua comum no estudo dos manuais de estratégia militar e para receber as instruções de mando. No I Encontro das Mulheres Zapatistas com as Mulheres do Mundo, 14 outra insurgenta relata:

\begin{abstract}
Estando na montanha aprendemos muitas coisas. Se não sabíamos ler e escrever, falar a castilla, nos ensinava à nós os companheiros. Tudo o que não aprendemos em nossa casa, aí aprendemos tudo na montanha. Estando como insurgenta é nossa obrigação aprender todo tipo de trabalho. Aprendemos o político, o militar e o cultural (Tradução nossa).
\end{abstract}

O EZLN e os anos de formação político-militar clandestina na Selva Lacandona foram uma das primeiras instâncias de formação política e educativa das Zapatistas. Da mesma forma o CCRI-CG figura como instância formativa para a base civil Zapatista. Entre aquelas que se formaram neste espaço estão as Comandantas Ramona e Esther, quem esclarece "não sabia falar espanhol. Fui à escola, porém ali não aprendi nada. Porém, quando ingressei na organização, aprendi a escrever e a falar espanhol, o pouco que sei, estou fazendo a luta" (EZLN, 2001: 217, tradução nossa). Com a

\footnotetext{
14 Documentário "El derecho de ser feliz". Disponivel em:
} https://www.youtube.com/watch?v=aWkKwdGKtxE. Data de acesso: janeiro de 2018. 
Florescer dos feminismos na luta das mulheres indígenas e camponesas da américa latina | Lia Pinheiro Barbosa

consolidação do projeto autonômico Zapatista, as mulheres começam a ocupar espaços de participação política, seja na estrutura militar do EZLN, ou na máxima instância de autoridade civil, o CCRI-CG. Atualmente, estas desempenham cargos no Governo Autônomo, nas Juntas de Bom Governo (JBG), em outras áreas de trabalho nos Municípios Rebeldes Autônomos Zapatistas, como parteiras e curandeiras, como Promotoras de Saúde, Promotoras de Educação, Promotoras de Agroecologia, Coordenadoras Gerais de Zona.

Nessa trajetória, os Zapatistas realizaram a transição da guerra das armas pela guerra desde a palavra. E nesse reordenamento da luta, Ramona e Esther assumiram um papel político fundamental como educadoras. Antes de sua incorporação à luta zapatista, Ramona era catequista em comunidades indígenas e uma das primeiras mulheres a integrar o CCRI-CG, com o cargo de Comandanta, máximo cargo civil. A ela foi designada a função simbólica de ser a portadora da bandeira nacional mexicana, da rosa vermelha e do bastão de mando, simbologia que pode ser interpretada como o novo sincretismo sobre o qual se deseja refundar a nação moderna mexicana na ótica Zapatista (MILlÁN, 2014). Em sua condição de mulher indígena Zapatista, Ramona enfatizava que a luta das mulheres era central, "porque chegamos a entender que para mudar está má situação, temos que participar. Não todas na luta armada, mas também em diferentes trabalhos em nossas comunidades" (Tradução nossa). E afirmava: "o zapatismo não seria o mesmo sem suas mulheres rebeldes. As mulheres índias também temos levantado nossa voz e dito: nunca mais um México sem nós. Nunca mais uma rebelião sem nós" (Tradução nossa).

Reivindicar uma nação e uma rebelião com a participação efetiva das indígenas é demandar o reconhecimento de sua existência como sujeito político, um a priori na despatriarcalização do poder patriarcal instituído no Estado, ou mesmo aquele erigido em suas comunidades e nos diferentes espaços de atuação política como mulheres Zapatistas. A Comandanta Esther se tornou um símbolo da luta das Zapatistas na denúncia e no enfrentamento do patriarcado institucionalizado no Estado. Primeira indígena a adentrar ao Congresso Nacional Mexicano, Esther foi enfática em seu discurso (EZLN, 2001: 387-390): 
Florescer dos feminismos na luta das mulheres indígenas e camponesas da américa latina | Lia Pinheiro Barbosa

Meu nome é Esther, porém isso não importa agora. Sou zapatista, porém isso tampouco importa nesse momento. Sou indígena e sou mulher, e isso é o único que importa agora. Esta Tribuna é um símbolo. Por isso convocou tanta polémica. Por isso queriamos falar nela e por isso alguns não queriam que aqui estivéramos. E é um símbolo também que seja eu, uma mulher pobre, indigena e zapatista, que tome primeiro a palavra e seja minha a mensagem central de nossa palavra como zapatistas (Tradução nossa).

A presença de Esther no Congresso Nacional se traduz como um deslocamento da autoridade epistêmica do Estado, ao posicionar seu corpo e sua voz como expressão política das mulheres, pobres e indígenas, que já não estão dispostas a aceitar as condições de vida e de exploração impostas pela cultura politica ocidental. Por meio da Pedagogia da Palavra, as Comandantas Ramona e Esther realizaram um expressivo trabalho de formação política de base junto às mulheres indigenas, ademais do diálogo que estabeleceram como porta-vozes do Zapatismo com outras lutas e teóricas feministas latinoamericanas. Não são poucos os relatos em que se reconhece o papel de ambas na conformação da consciência politica das Zapatistas. Um reconhecimento advindo da Pedagogia do Exemplo daquelas que antes não sabiam ler, escrever e falar castilla e conseguiram tornar-se simbolo da resistência das Zapatistas, conforme atesta uma Coordenadora de Saúde do Caracol III (EZLN, 2013, p. 38):

A Comandanta Ramona, foi ela quem fez esse esforço para nós. Ela não sabia ler nem escrever, nem falar a castilla. [...] É um exemplo essa companheira que já fez o esforço, ela já é o exemplo que vamos seguir mais adiante para fazer mais trabalhos, para demonstrar o que sabemos em nossa organização (Tradução nossa).

Nos discursos das jovens Zapatistas, a Comandanta Ramona se revela como inspiração e sabedoria, eterno simbolo da luta das Zapatistas; a Comandanta Esther se traduz como ousadia revolucionária das mulheres indigenas, quem subverteu a condição subalterna de ser uma Sem Rosto e uma Sem Voz, e pisou onde nunca se permitiu a uma indigena pisar: o Congresso Nacional, exigindo o direito de dizer sua palavra, que finalmente é a palavra coletiva das mulheres indigenas. Na conformação da consciência de luta como mulheres indigenas, a Pedagogia da Palavra incide em um reordenamento do gênero (MILLÁN, 2014), ao deslocar e subverter as representações da mulher indígena no contexto do discurso ocidental moderno e do Estado-nação. Portanto, as Zapatistas edificam, no âmbito da 
Florescer dos feminismos na luta das mulheres indígenas e camponesas da américa latina | Lia Pinheiro Barbosa

luta feminista, paridades impensáveis (LAGARDE, 1999) e aportam em uma teorização própria ao antecipar, no campo teórico-epistêmico e político, a abordagem de gênero, em uma redefinição epistêmica do feminismo, de um "ser Zapata, sendo mulheres" (LAGARDE, 1999).

\section{Luta das mulheres, conceito insurgente, revolucionário, rebelde e autônomo das Zapatistas}

Uma condição imprescindivel para compreender o Zapatismo é ter presente que trata-se de uma luta fortemente enraizada nos referentes da cosmovisão maia, da qual se desprende uma filosofia própria que confere outros sentidos ao ser, estar, pensar o mundo e a si mesmos no mundo, ou seja, uma dimensão epistêmica que orienta a base do pensamento e da vida sócio-comunitária. Há, pois, uma dimensão epistêmica da racionalidade Zapatista (BARBOSA, 2015), que emerge da cosmovisão, da cultura e das línguas maias e que constitui o eixo nodal do pensamento e do projeto político autonômico Zapatista, uma vez que lhe permite tanto problematizar a realidade sociocultural e política em perspectiva histórica, como decifrá-la a partir dos referentes da memória história da resistência, das experiências e dos saberes construídos milenarmente (BARBOSA, 2016). Assim, um dos principais conceitos maias é o tik (nosotros) - nós, que enfatiza uma identidade na perspectiva do coletivo, não do indivíduo (LENKERSDORF 2002). ${ }^{15}$ O tik é a coluna vertebral dos Zapatistas na consolidação do seu pensamento, de sua identidade e subjetividade políticas. Da chamada ação nosótrica se deriva uma forma de organização sociopolítica e uma intersubjetividade que determina os principios de sociabilidade comunitária, situa o lugar social de cada membro da comunidade e demarca o olhar coletivo acerca da realidade social interna e externa das comunidades, na perspectiva de uma nova comunalidade, um novo comon (LEYVA-SOLLANO, 1995).

A luta das Zapatistas se insere na dialética do novo comon. Para interpretar a sua concepção do feminismo é preciso compreender a lógica de ordenamento social predominante nas comunidades indigenas mesoamericanas entre os gêneros, a partir do conceito de dualidade, uma

\footnotetext{
15 Os trabalhos de Carlos Lenkersdorf se referem à cosmovisão maia tojolabal. Entretanto, cada etnia maia possui uma matriz linguística própria, com conceitos específicos que expressam seu pensamento e sua forma de ser, estar, pensar e sentir no mundo.
} 
Florescer dos feminismos na luta das mulheres indígenas e camponesas da américa latina | Lia Pinheiro Barbosa

elaboração conceitual da natureza e dos seres humanos em chave dual. Conforme afirma Marcos (2011), a dualidade mesoamericana é um conceito que articula discursos aparentemente contraditórios, mas que, em realidade, demarcam outra lógica com relação à posição dos sujeitos no tempo e no espaço (Marcos, 2011).

No mundo indigena não existem categorias mutuamente excludentes, uma vez que os fundamentos cosmológicos mesoamericanos se baseiam no princípio do equilíbrio. A dualidade é o que caracteriza a natureza dos seres, entre eles o gênero feminino e masculino. A fluidez do gênero se faz presente na filosofia mesoamericana e o processo de construção do pensamento evita promover uma divisão por meio da exclusão. A dualidade masculino-feminino é básica na cosmologia maia e seu vínculo se dá por meio do conceito de complementaridade - entre homem/mulher, entre ser humano/natureza uma forma de interpretação do ser (mulher e homem) em inter-relação com o universo em perspectiva complementaria. Dessa maneira, na construção do pensamento mesoamericano há a fusão do feminino e do masculino em um princípio singular, porém polarizado, no qual as divindades se concebiam em pares, a partir do principio da complementariedade, com o intuito de manter as duas forças em equilíbrio (MARCOS, 2011).

Contudo, alguns estudos questionam essa interpretação da complementariedade como exortação do caráter harmonioso e equilibrado da ordem comunitária e expressão da igualdade entre os gêneros nas sociedades indigenas (PRIETO et. al., 2006; RIVERA-ZEA, 2008), demonstrando a existência de uma trama complexa de hierarquias e igualdades nas relações de gênero e que abrem e/ou fecham opções para as indígenas.

Se retomarmos a Lei Revolucionária de Mulheres, vemos claramente o princípio da dualidade complementária, frente à exigência do direito de participação política igualitária como mulheres. Em sua teorização e vivência da dualidade complementaria, nos deparamos com conceitos genuínos, tais como lajan lajan 'aytik (Lajan lajan - igualdade e aytik - estamos nós), estar em pé de igualdade, ou ainda, formamos juntos em comunidade de iguais (LENKERSDORF, 2002). Portanto, a posição de par/complementária embasa a luta das Zapatistas pelo direito de igualdade em perspectiva símil à dos 
Florescer dos feminismos na luta das mulheres indígenas e camponesas da américa latina | Lia Pinheiro Barbosa

homens, sobretudo pelo predomínio da divisão sexual do trabalho, tão presente nas comunidades zapatistas.

É importante destacar que em muitos povos originários a igualdade entre os gêneros se constrói pelo princípio da diferença, ou seja, a alteridade dos gêneros é necessária para produzir a diferença de maneira processual, conformando outras noções de dominação, relações sociais e espaços públicoprivados diferentes daquelas pertencentes ao mundo ocidental (OVERING, 1986, MARCOS, 2011).

Em diferentes relatos das Zapatistas encontramos a reivindicação de ser reconhecidas como iguais, em construir a autonomia para as mulheres e os homens no caminhar lado a lado, caminhar em pares. Assim, o princípio do caminhar em pares, em pé de igualdade é o fundamento da proposta feminista das Zapatistas e o acordo é a mediação pedagógica e política para seu alcance. A assembleia, instância legítima de representação coletiva no âmbito das comunidades Zapatistas (BARBOSA, 2015), media a relação homem/mulher no marco da lei de usos e costumes e na Lei Revolucionária de Mulheres. Conforme uma mulher Base de Apoio Zapatista do Caracol IV: "com nossa consciência vamos lutando, porém sozinhas não podemos lutar, sempre vamos juntas de mãos dadas com nossos companheiros, porque a luta deve ser de pares" (Tradução nossa). ${ }^{16}$ Uma Promotora de Educação do Caracol II enfatiza (EZLN, 2013, p. 18):

Com esta chegada da propriedade privada ocorreram três grandes males, que são a exploração de todos, homens e mulheres, mas mais ainda das mulheres [...] a opressão dos homens sobre as mulheres por sermos mulheres e [...] a discriminação por sermos indígenas. [...] Estamos falando de uma luta revolucionária e uma luta revolucionária não a fazemos só os homens nem só as mulheres, é tarefa de todos (Tradução nossa).

A fala da Promotora de Educação evidencia dois planos da luta política das Zapatistas: o de categorização das opressões históricas contra as mulheres, enraizadas no patriarcado e nas lógicas de opressão próprias da interseccionalidade entre gênero, raça e classe social. Constituem raízes da discriminação e do racismo estrutural por ser indigena, herdeira da dialética colonial, de introjeção da dominação e da subordinação em seus corpos e em suas subjetividades como mulheres indígenas. Nesse aspecto, as Zapatistas

16 Registro em diário de campo, agosto de 2010. 
Florescer dos feminismos na luta das mulheres indígenas e camponesas da américa latina | Lia Pinheiro Barbosa

comungam com as mulheres da CLOC e do Feminismo Comunitário o reconhecimento de um lugar de mestiçagem e de classe que as subjuga historicamente como indígenas e camponesas, portanto, é condição sine qua no considerar o caráter interseccional das opressões de gênero.

Em segundo lugar, ao situar a natureza de uma luta que se propõe revolucionária, as Zapatistas definem que esta deve assumir a postura de pares / complementaria em seu âmago combativo: os pares masculino/feminino na infância, na juventude e na vida adulta, em sua totalidade orgânica como comunidade, na perspectiva da emancipação das mulheres e dos homens. As Zapatistas insistem na necessidade histórica de pensar-se em termos posicionais, na interseccionalidade entre gênero, etnia e classe social, posições que demarcam condições históricas de subalternidade como mulheres, indigenas, camponesas e pobres. Vale destacar que um dos principais elementos em comum entre a concepção de luta das Zapatistas e aquelas erigidas pelo Feminismo Camponês e Popular e o Feminismo Comunitário consiste em que são mulheres que reivindicam um lugar justo de participação política dentro de suas organizações e uma equidade de gênero demarcada por outros códigos da estrutura social e cultual no mundo indígena, destinados a organizar, a estruturar e a manter a vida sóciocomunitária, sempre em articulação com a coletividade.

Recusam-se, pois, a articular sua luta de maneira exógena, dado que em sua convicção política a emancipação é parte de um projeto político popular, que deve ser fundado em outro paradigma de gênero, em que participam mulheres e homens. Aqui reside um diferencial muitas vezes dificil de ser compreendido por algumas correntes do feminismo e, sobretudo, entre os feminismos urbanos. A interseccionalidade, na perspectiva das mulheres indigenas, revela visões diferenciadas nas relações de gênero e que deveriam ser reconhecidas como um aporte importante no debate mais amplo dos feminismos populares.

Nesse marco, a Comandanta Esther, em saudação à Via Campesina, convoca: 17

Irmãs, mulheres, indígenas, camponesas, lhes queremos dizer que se organizem para lutar contra o neoliberalismo que nos humilha, que nos explora e que nos quer desaparecer como indigenas, como

17 Disponivel em: http://palabra.ezln.org.mx/comunicados/2003/2003_09_b.htm. Data de acesso: fevereiro de 2018. 
Florescer dos feminismos na luta das mulheres indígenas e camponesas da américa latina | Lia Pinheiro Barbosa

camponesas e como mulher. Também queremos dizer aos homens que respeitem nosso direito como mulher, porém não vamos pedir como um favor, mas vamos a forçar os homens a nos respeitarem. Porque como mulheres que somos nos querem humilhar o rico, mas também o homem que não é rico, ou seja, o que é pobre como nossos esposos, nossos irmãos, nossos pais, nossos filhos, nossos companheiros de luta. Claro afirmamos que quando exigimos respeito pelas mulheres, não o exigimos apenas dos neoliberais. Nós também vamos forçar àqueles que lutam contra o neoliberalismo e dizem que são revolucionários, mas em casa são como o Busch (Tradução nossa).

No dia Internacional da Mulher Rebelde, a Comandanta Esther profere o seguinte discurso (EZLN, 2001, p. 217):

Às mulheres de todo o mundo, lhes dizemos que lutemos todas juntas. Nós temos que lutar mais porque somos indígenas, estamos triplamente desprezadas: como mulher indigena, como mulher e como mulher pobre. Porém, as mulheres que não são indígenas também sofrem, por isso vamos convidá-las a todas a que lutam, para que já não sigamos sofrendo (Tradução nossa).

As Zapatistas lançam novos elementos para pensar as violências históricas contra as mulheres, especialmente as indigenas, e circunscrevem outros referentes na construção da equidade entre gêneros, baseado nos fundamentos da filosofia maia, nos princípios do equilíbrio e da harmonia da dualidade complementaria. Ampliam sua compreensão de luta como mulheres, ao transcender o debate analítico na elaboração de uma concepção genuína, mui outra de sua própria luta, erigida da experiência de insurgir como mulheres indigenas e Zapatistas. Um aspecto importante da teorização das Zapatistas é o fato de não incorporarem diretamente o conceito de feminismo. Não encontramos em seus discursos e escritos menção explícita de uma identidade feminista circunscrita a uma determinada corrente teórica do feminismo. As Zapatistas exercem sua autonomia epistêmica, ao explicitar a forma como constroem sua subjetividade política e sua luta como mulheres: "Nós não usamos a palavra feminismo porque sempre falamos luta das mulheres. E existem diferentes palavras para dizer o mesmo, porque entendemos que é o mesmo, porém o dizemos de nossa maneira, que é diferente" (Tradução nossa). ${ }^{18}$

A autonomia epistêmica das Zapatistas, em dizer sua palabra, em consonância com outros delineamentos teórico-politicos das feministas, mas dito de forma diferente, tem suscitado articulações, ao afirmar "que o

18 Registro em diário de campo, março de 2018. 
Florescer dos feminismos na luta das mulheres indígenas e camponesas da américa latina | Lia Pinheiro Barbosa

zapatismo coincide com alguns elementos das teses do feminismo, pois propõe uma nova ética do poder, que não seja patriarcal” (EZLN, 1996: 158, tradução nossa). Entretanto, as aproximações entre as Zapatistas e as teóricas feministas também apresentam campos de tensão comumente articulados pelos três aspectos que apresentei ao início do artigo: o sujeito e os corpos do feminismo; a colonização discursiva e o privilégio epistêmico do feminismo ocidental e a descolonização do feminismo.

O privilégio e a autoridade epistêmicos constituem elementos nodais nas tensões estabelecidas entre as Zapatistas e as teóricas feministas. No Primeiro Encontro Internacional, Politico, Artístico, Esportivo e Cultural de Mulheres que Lutam, realizado em março de 2018, no Caracol IV, as Zapatistas explicitaram esta tensão:

\footnotetext{
Porque não só os homens, também existem mulheres das cidades que nos desprezam, que porque não sabemos da luta das mulheres, porque não lemos livros onde as feministas explicam como deve ser $\mathrm{e}$ tantas coisas que dizem e criticam sem saber como é a nossa luta (Tradução nossa).
}

Evidencia-se a carga simbólica e material do racismo epistêmico, muitas vezes presente no labor teórico de "emancipar as mulheres" e que está suscetivel de reproduzir um colonialismo, expresso em um etnocentrismo intelectual, de imposição de uma teoria que se pretende universal e que demarca, sob critérios categoriais ocidentais, por vezes a-históricos, quais os elementos que definem uma luta que, necessariamente, deve ser denominada feminista, quem de fato é feminista ou quais lutas podem ser consideradas realmente como feministas.

A crítica ao colonialismo das práticas discursivas do feminismo hegemônico tem sido amplamente realizada por outras teóricas feministas, que se posicionam na defesa de outros feminismos, desde o Abya Yala (MÉNDEZ-TORRES etl. al., 2013; ESPINOSA-MIÑOSO, CORREAL \& MUÑOZ, 2014; MILLÁN, 2014). Entretanto, mesmo no reconhecimento de outras genealogias da luta das mulheres, ainda perdura uma estrutura teóricometodológica que enquadra a análise e, portanto, delimita o sujeito e os corpos do feminismo. As Zapatistas, as mulheres da CLOC e as mulheres do Feminismo Comunitário são enfáticas, ao afirmar que necessitam um feminismo útil para a luta dos povos. Aqui, situo a reflexão de uma militante 
Florescer dos feminismos na luta das mulheres indígenas e camponesas da américa latina | Lia Pinheiro Barbosa

da CLOC, 19 ao problematizar que o enquadramento teórico almejado pelas teóricas feministas, além de um caráter hermético, impede um enriquecimento do feminismo por uma tendência ao veto a outras expressões de luta das mulheres. Para essa mesma militante, a urgência por definir um marco teórico, em suas palavras, como um feminismo pós-colonial, descolonial, decolonial conduz a um labirinto conceitual incompreensivel para as mulheres que constroem sua luta no campo popular. As Zapatistas corroboram com esta reflexão, ao mencionarem que são muitas palavras novas, que nem sempre conseguem entender, ${ }^{20}$ mas que talvez estejam dotadas do mesmo sentido atribuído por elas em sua luta como mulheres indígenas. Há um caminho sinuoso ou mesmo um fosso no diálogo entre as Zapatistas e as teóricas feministas, decorrente de uma suposta autoridade epistêmica presente nos feminismos ocidentais.

Entretanto, há um esforço de autorreflexão crítica entre as teóricas feministas com relação à descolonização do feminismo, à superação do etnocentrismo intelectual e às lógicas de poder que invisibilizam e/ou despreciam a existência das mulheres indígenas e camponesas (HERNÁNDEZCASTILLO, 2014). Reconhece-se que é necessário ampliar o entendimento das lutas, transpondo o campo individual ao coletivo, no aprender a escutar e a olhar, ensinamento epistêmico do Zapatismo, sem a pretensão de uma escuta averiguadora ou orientadora de como ser / tornar-se feminista. Ao contrário, de uma aprendizagem em comunhão com as teorias construídas por outras mulheres do campo popular.

Como expressão desse exercício das teóricas feministas, destaco alguns trechos da "Carta à Comandanta Ramona", escrita por Mercedes Olivera, reconhecida lutadora social e intelectual feminista mexicana, lida durante o "Conversatorio Miradas, Escuchas, Palabras: ¿Proibido pensar? realizado em 2018, uma reflexão após participar do Primeiro Encontro Internacional, Político, Artístico, Esportivo e Cultural de Mulheres que Lutam:

Para nós que vivemos fora, foi maravilhoso vê-las atuando como uma só, perceber seu ritmo de tolerância e harmonia [...] e recebendo-nos com uma escuta exemplar. [...] As jovens Zapatistas nos deram às velhas e novas feministas uma lição teórica e prática do feminismo revolucionário que praticam em seus caracóis, sem necessidade sequer de dar-lhe o nome. Desde a convocatória dirigida às mulheres

\footnotetext{
19 Registro em diário de campo, março de 2018.
}

20 Registro em diário de campo, março de 2018. 
Florescer dos feminismos na luta das mulheres indígenas e camponesas da américa latina | Lia Pinheiro Barbosa

que lutam, exerceram sua sabedoria: nenhuma se sentiu excluída e chegamos todas as que lutamos. [...] E que impressionante, Ramona, que estivemos presentes, mulheres com posições diferentes, compartilhando sem conflito. Todas pudemos nos expressar, nos sentir unidas e fortes porque todas lutamos, certamente de muitas diferentes maneiras (Tradução nossa).

\section{Dos diálogos com e entre os feminismos: reflexões finais}

Conforme argumentei ao longo do artigo, na perspectiva dos feminismos populares da América Latina e da luta contra o patriarcado e o capitalismo, em defesa da terra, do território, da reforma agrária e do enfrentamento do capital transnacional no campo, considero que as Zapatistas dialogam com duas abordagens em curso: o Feminismo Camponês e Popular e o Feminismo Comunitário. O diálogo entre as três abordagens manifesta-se no marco teórico-epistêmico de suas concepções de luta como mulheres indigenas e camponesas ou, ainda, na presença das mulheres da CLOC e do Feminismo Comunitário em eventos convocados pelas Zapatistas. Nessa direção, as Zapatistas comungam com as mulheres da CLOC a natureza de um projeto político de caráter popular. O anseio por instaurar outro paradigma de gênero cobra vitalidade no fato de que, tanto as Zapatistas, como as mulheres da CLOC pertencem a organizações com um projeto político de emancipação humana, no qual participam mulheres e homens, o que conduz à reivindicação da participação paritária, com igualdade de direitos. A luta por direitos é concebida numa perspectiva de simultaneidade, isto é, da garantia de direitos individuais como mulheres, bem como de direitos coletivos (como organizações).

Do ponto de vista teórico, considero que as Zapatistas dialogam com o conceito de entroncamento patriarcal desenvolvido pelo Feminismo Comunitário, ao problematizar em chave filosófica, o lugar social historicamente imposto às mulheres e aos homens indígenas, a violência e a expropriação dos seus corpos, dos seus territórios, dos seus pensamentos e de suas temporalidades; ao posicionar-se frente ao colonialismo e as múltiplas expressões do patriarcado, seja no plano institucional do Estado-nação, ou mesmo nos enfrentamentos do patriarcado interno, em suas comunidades. $\mathrm{O}$ par complementário da cosmovisão maia se aproxima do par-politico WarmiChacha na estratégia politica para a despatriarcalização e a emancipação de mulheres e homens, em coletivo e em pares. 
Florescer dos feminismos na luta das mulheres indígenas e camponesas da américa latina | Lia Pinheiro Barbosa

Assim como pautado no Feminismo Comunitário, as Zapatistas partem do princípio de que a despatriarcalização ocorre na luta coletiva comunitária, posto que a comunidade é locus do ethos identitário comum, da memória ancestral, da racionalidade indígena, da luta política da qual participam todos. Comungam, ainda, o reconhecimento de que o patriarcado provoca um desequilíbrio na comunidade, uma vez que alija as mulheres, intensificando sua condição de sujeito subalterno.

As Zapatistas se forjam como sujeito político e circunscrevem na história política do Zapatismo um nosotros feminino (VRIJEA, 2000) e uma epistemologia de nosotras, que remete a um processo de elaboração teórica própria como mulheres, a uma coletividade comunitária, permeada pelo pensamento e cultura indigenas, que visa o fortalecimento dos processos de interdependência entre os membros das comunidades. Nessa direção, as mulheres indígenas se definem como um coletivo dentro da comunidade, e não pretendem promover com ela uma ruptura, mas construir um processo de emancipação como sujeito coletivo.

É fundamental destacar que o processo de construção de uma consciência de gênero entre as Zapatistas nasceu da mesma condição de mulheres indigenas exploradas nas históricas relações coloniais no México e do próprio processo de violência sobre seus corpos e de seus filhos. Em outras palavras, não foi um processo imediato de ganho de consciência feminista e de luta contra o patriarcado, mas sim de libertar-se de uma relação de opressão colonial e capitalista. Entretanto, a Lei Revolucionária de Mulheres e o próprio processo de participação em uma luta revolucionária e emancipatória permitiram às Zapatistas elaborar sua própria concepção em torno à luta das mulheres, além das pontes de diálogo com as feministas acadêmicas e outros feminismos populares.

As Zapatistas revolucionaram a história política mexicana e latinoamericana ao criar a Lei Revolucionária de Mulheres, sobretudo pela capacidade de organização das mulheres, ao forjar-se como sujeito político que, sob o signo da rebeldia e na construção de novas condutas, impugnam os modelos tradicionais de subordinação por etnia e gênero (BUSTAMANTE, 2003). Somente em território Zapatista as indigenas conseguiram implementar o que preconiza a lei, uma conquista revolucionária no 
Florescer dos feminismos na luta das mulheres indígenas e camponesas da américa latina | Lia Pinheiro Barbosa

enfrentamento da marca colonial intrínseca ao "modelo tradicional de mulher" imposto à indígena.

Ainda há desafios importantes, por exemplo, que a Lei Revolucionária de Mulheres seja estudada permanentemente entre todas, para que não tenham receio de tomar o direito, conforme avaliam as Zapatistas. Outro desafio é superar o machismo interno e o que denominam como problema de saia, situações de conflito familiar que persistem nas comunidades, em que os homens tentam limitar a participação das mulheres na assunção dos cargos, o que requer uma formação de base de caráter comunitário para superar situações de tensão e impulsar a dualidade complementaria entre pares.

Em que pese esses desafios, as Zapatistas afirmam que avançam takal takal, pouco a pouco, e buscam fortalecer suas alianças, na reafirmação de seus corpos como territórios de resistência, bem como na permanente denúncia da GBI e do feminicídio como um crime de Estado. Conforme a Comandanta Miriam:21

\begin{abstract}
Depois de 10 anos do I Encontro das Zapatistas, decidimos realizar outro, porque é importante nos reunir, embora sejamos diferentes. Porque há momentos que só ficamos em nossa casa, em nossa comunidade e não sabemos o que está acontecendo fora, fora do México. Assim, decidimos fazer o Encontro para fazer florescer sementes, para florescer à nós, para mostrar à nós, as mulheres, que somos valorosas e sabemos sozinhas, assim como os homens também podem sozinhos. As mais jovens, pois, estão melhor porque já sabem ler, escrever. Nós não sabíamos ler, falamos pouco a castilla; porém, hoje, elas já sabem e têm outras tarefas porque agora tem que saber da luta das mulheres para além de Chiapas, do México, e em outros lugares (Tradução e grifos nossos).
\end{abstract}

No processo de fazer florescer sementes, as Zapatistas, assim como as indígenas do Feminismo Comunitário e as camponesas da Articulação de Mulheres da CLOC fazem florescer outras concepções de sua luta como mulheres. Aliás, a palavra luta é a raiz e enraíza-se no discurso e na práxis politica dessas mulheres, na tessitura da compreensão e da crítica ao patriarcado como sistema de opressões de gênero. É na luta que tecem sua concepção teórico-epistêmica e política acerca dos feminismos, das diferentes formas de ser feministas, e dos caminhos para a emancipação, em coletivo e em pares. As Zapatistas se unem às mulheres do Congresso Nacional Indigena

\footnotetext{
21 Registro em diário de campo, março de 2018.
} 
Florescer dos feminismos na luta das mulheres indígenas e camponesas da américa latina | Lia Pinheiro Barbosa

sob a consigna "Nossa luta é pela vida", que explicita a natureza do projeto político para os povos indígenas mexicanos, especialmente para as mulheres: outro mundo em que se possa viver, sem medo de ser mulher. A transcendência teórico-epistêmica e política de LUTAR PELA VIDA, tarefa revolucionária das Zapatistas, mas também das mulheres da Articulação de Mulheres da CLOC, do Feminismo Comunitário se vincula à memória histórica de sua resistência, ao recuperar a palaura histórica daquelas que as antecederam, em um movimento dialético que se assemelha ao conceito aymara ñawpaj manpuni, um "olhar para trás que também é um ir para frente" (CUSICANQUI 1984, tradução nossa.), ou seja, retomar o passado, com uma projeção de futuro que se conjuga no presente.

Um movimento histórico que não é linear, mas em ciclos espirais (e daí a referência à simbologia do Caracol), que nos permitem, por um lado, interpretar a memória coletiva longa, marcada por ritos, heranças simbólicas, que expressam a permanente violência colonial sobre o mundo indígena, seus corpos, conhecimentos e crenças espirituais e, por outro, apresenta memórias coletivas curtas que se conectam, coexistem, antagonizam com o horizonte colonial.

Finalizo esta reflexão enfatizando que o grito de "Já Basta" das Zapatistas permanece a ecoar e a dialogar com os feminismos e a luta das mulheres. Na reflexão e consolidação do caminhar em pares, concepção feminista revolucionária, insurgente, rebelde e autônoma das Zapatistas, estas seguirão aportando ao debate dos feminismos populares contemporâneos, lançando outros referentes teórico-conceituais e políticos para desvelar os desafios e as tensões com relação à justiça de gênero, como também nutrindo a utopia de um mundo onde caibamos todas. Ao lado da Articulação de Mulheres da CLOC, das indígenas do Feminismo Comunitário e de outras mulheres que lutam seguirão semeando solos férteis ao florescimento das sementes da luta antipatriarcal, anticolonial, anticapitalista e antirracista, pela emancipação das mulheres.

\section{Referências Bibliográficas}

ALTAMIRANO-JIMENEZ, Isabel. Indigenous Encounters with Neoliberalism. Place, Women and the Environment in Canada and Mexico. Vancouver: UBC Press, 2013. 
Florescer dos feminismos na luta das mulheres indígenas e camponesas da américa latina | Lia Pinheiro Barbosa

ANAMURI. Hacia la construcción del Feminismo Campesino y Popular. Chile: El Correo de las Mujeres del Campo - ANAMURI, 2015.

ARMAS, Margarita Nolasco. Siempre rebeldes: los indígenas de Chiapas. In: NOLASCO, Margarita et. al. Los pueblos indigenas de Chiapas: atlas etnográfico. México: INAH, 2008, p. 181-190.

BARBOSA, Lia Pinheiro. Paradigma epistêmico do campo e a construção do conhecimento na perspectiva dos movimentos indígenas e camponeses na América Latina. In: SANTOS, Arlete Ramos (org.). Educação e movimentos sociais: análises e desafios. Jundiaí: Paco Editorial, 2019, p. 279-299.

Mulheres Zapatistas e a Pedagogia da Palavra no tecer da outra educação. In: CASTRO, Amanda Motta \& MACHADO, Rita de Cássia Fraga. Estudos Feministas: mulheres e educação popular. São Paulo: LiberArs, 2018, p. 25-47.

Educação rebelde e autônoma na práxis revolucionária Zapatista. In: REBUÁ, Eduardo \& SILVA, Pedro. Educação e filosofia da práxis: reflexões de início de século. Rio de Janeiro: Letra Capital, 2016, p. 48-79.

Educación, resistencia y movimientos sociales: la praxis educativo-politica de los Sin Tierra y de los Zapatistas. México: LIBRUNAM, 2015.

BUSTAMANTE, Mercedes Olivera. Igualdad de género y etnia: desafios para las mujeres indígenas chiapanecas. In: GALL, Olivia. Chiapas - Sociedad, Economia, Política, Cultura. México: UNAM, 2013, p. 235-260.

CABNAL, Lorena. Feminismos diversos: el feminismo comunitario. España: ACSUR - Las Segovias, 2010.

CASTRO, Mafalda Galdames. Hacia la construcción del Feminismo Campesino y Popular. El correo de las mujeres del campo. Chile: ANAMURI, 2015, p63-33.

CHIRIX, Emma. Cuerpos, poderes y políticas: mujeres mayas en un internado católico. Guatemala: Ediciones Maya' Na'oj, 2013.

CUSICANQUI, Silvia Rivera. Oprimidos pero no vencidos: luchas del campesinato aymara y qhecwa de Bolivia (1900-1980). Ginebra: UNRISD, 1984.

ESPINOSA-MIÑOSO, Yurdekys; CORRAL, Diana.G.; MUÑOZ, Karina. Ochoa. (editoras). Tejiendo de otro modo: feminismo, epistemología y apuestas descoloniales en Abya Yala. Colombia: Editorial UC, 2014.

ESPINOSA-MIÑOSO, Yurdekys. Etnocentrismo y colonialidad en los feminismos latinoamericanos: complicidades y consolidación de las hegemonías feministas en el espacio transnacional. In: ESPINOSA-MIÑOSO, Yurdekys; CORRAL, Diana.G.; MUÑOZ, Karina. Ochoa. (editoras). Tejiendo 
Florescer dos feminismos na luta das mulheres indígenas e camponesas da américa latina | Lia Pinheiro Barbosa

de otro modo: feminismo, epistemología y apuestas descoloniales en Abya Yala. Colombia: Editorial UC, p. 309-324.

EZLN. Participación de las Mujeres en el Gobierno Autónomo. Cuaderno de Textos del Primer Grado del Curso de "La Libertad según 1@s Zapatistas. México, 2013.

Marcha del Color de la Tierra. Comunicados, cartas y mensajes del Ejército Zapatista de Liberación Nacional. México: Rizoma, 2001.

Crónicas Intergalácticas. Primer Encuentro Intercontinental por la Humanidad y contra el Neoliberalismo. Chiapas: Planeta Tierra, 1996.

Documentos y comunicados $1,1^{\circ}$ de enero / 8 de agosto de 1994. México: ERA, 1994.

FEDERICI, Silvia. La inacabada revolución feminista. Mujeres, reproducción social y lucha por lo común. Colombia: Ediciones desde Abajo, 2014.

GALINDO, Maria. No se puede descolonizar sin despatriarcalizar. Teoria y propuesta de la despatriarcalización. Bolivia: Mujeres Creando, 2013.

GREEN, Joyce Audry. Making Space for indigenous Feminism. Canadá: Fernwood, 2007.

Hernández, Rosalva. Aída. Algunos aprendizajes en el difícil reto de descolonizar el feminismo. In: MILLÁN, Márgara. Más allá del feminismo: caminos para andar. México: Red de Feminismos Descoloniales, 2014, p. 183212.

LAGARDE, Marcela. Insurrección zapatista e identidad genérica: una visión feminista. In: LOVERA, Sara Lovera \& PALOMO, Nellys. Las alzadas. México: CIMAC / Convergencia Socialista, 1999, p. 145-179.

LENKERSDORF, Carlos. Filosofar en clave tojolabal. México: Editora Porrúa, 2002.

LEYVA-SOLLANO, Xóchitl. Del comón al leviatán (Síntesis de un proceso sociopolítico en el medio rural mexicano. América Indigena, vol. LV, números. 1-2, 1995, p. 201-234.

MASIOLI, Etelvina. Feminismo Campesino y Popular. E1 correo de las mujeres del campo. Chile: ANAMURI, 2015, p. 59-62.

MARCOS, Sylvia. Mujeres, indigenas, rebeldes, zapatistas. México: Ediciones Eón, 2011.

MÉNDEZ-TORRES, Georgina. et. al. (coords). Senti-pensar el género. Perspectivas desde los pueblos originarios. México: Red Interdisciplinaria de Investigadores de los Pueblos Indios de México / Red de Feminismos Descoloniales, 2013. 
Florescer dos feminismos na luta das mulheres indígenas e camponesas da américa latina | Lia Pinheiro Barbosa

MÉNDEZ-TORRES, Georgina. Mujeres Mayas-Kichwas en la apuesta por la descolonización de los pensamientos y corazones. In: MENDÉZ-TORRES, Georgina et. Al. Senti-pensar el género. Perspectivas desde los pueblos originarios. México: Red Interdisciplinaria de Investigadores de los Pueblos Indios de México / Red de Feminismos Descoloniales, 2013, p. 27-62.

MILLÁN, Márgara. Des-ordenando el género / ¿Des-ordenando la nación? El Zapatismo de las mujeres indígenas y sus consecuencias. México: UNAM, 2014.

- Las zapatistas de fin de milenio. Hacia políticas de autorepresentación de las mujeres indígenas. Revista Chiapas, $n^{\circ} 3$, 1996, p. 19-32.

MOHANTY, Chandra Talpade. Bajo los ojos del Ocidente. Academia feminista y discurso colonial. In: NÁVAZ Naváz, Liliana Suárez; HERNÁNDEZCASTILLO, Rosalba Aída. Descolonizar el Feminismo: teorias y prácticas desde los márgenes. Madrid: Cátedra, 2008, p. 112-121.

OVERING, Joana. 'Men control women? the "Catch 22" in the analysis of gender'. International Journal of Moral and Social Studies. 1,2: 135-156, 1986.

PRIETA, Mercedes. et. al. Respeto, discriminación y violencia: Mujeres Indigenas en Ecuador, 1990-2004.In: LEBON, Nathalie; MAIER, ELIZABETH. De lo Privado a lo Público: 30 años de lucha ciudadana de las mujeres en América Latina. México: Siglo XXI, 2009.

RIVERA-ZEA, Tarcilia. Mujeres indígenas americanas luchando por sus derechos. In: NÁVAZ Naváz, Liliana Suárez; HERNÁNDEZ-CASTILLO, Rosalba Aída. Descolonizar el Feminismo: teorias y prácticas desde los márgenes. Madrid: Cátedra, 2008, p. 331-350.

ROSSET, Peter. La reforma agraria, la tierra y el territorio: evolución del pensamiento de La Vía Campesina. Mundo Agrario. 17 (35): 1-21, 2016.

SEGATO, Rita. Gênero e colonialidade: em busca de chaves de leitura e de um vocabulário estratégico descolonial. E-Cadernos CES, 18: 105-131, 2012.

SEIBERT, Iridiane Graziela. Feminismo campesino y popular. Una propuesta de las campesinas de Latinoamérica". Disponível em: http://www.soberaniaalimentaria.info/numeros-publicados/60-numero29/454-feminismo-campesino-y-popular, 2017.

SMITH, Andrea. Conquest: Sexual Violence and American Indian Genocide. Cambridge: South End Press, 2005.

SUBCOMANDANTE INSURGENTE MARCOS. Especial Zapatista - medio siglo de victoriosa insurgencia zapatista. Resumen Latinoamericano, $\mathrm{n}^{\circ} 99$, enero-febrero de 2009. 
Florescer dos feminismos na luta das mulheres indígenas e camponesas da américa latina | Lia Pinheiro Barbosa

VIVEROS-VIGOYA, Mara. La sexualización de la raza y la racialización de la sexualidad en el contexto latinoamericano actual. Memoria del 1er. Encuentro Latinoamericano y del Caribe. La sexualidade frente a la sociedade. México, 2008.

VRIJEA, María Jaidopolu. Las mujeres indígenas como sujetos políticos. Revista Chiapas, n.9: 35-59, 2000. 